\title{
実世界指向メディアとしての次世代ロボット
}

Next Generation Robots as Real-world Oriented Media

安 西 祐一郎* *慶應義塾大学理工学部 Yuichiro Anzai* * Keio University

\section{1. 次世代ロボット技術の目標}

次世代ロボット技術の一つの方向は, 従来のロボットエ 学が扱っていたよりもはるかに複雑で状況変化の予測が 困難な（すなわちオープンな）環境における，人間と環境 のインタラクションを円滑にするための媒介 (メディア) 技術の開発に向かうことになるだろう。このような技術を 「実世界メディア技術」と呼ぶことにする。

ネットワークロボティクス, 分散ロボット・コンピュー タシステム, 人間・ロボット協調システム, マイクロロボッ トシステム，遠隔操作システム，インテリジェントハウス， 知的構造物, 知的輸送機器, 家電ネットワーク, 健康維持シ ステム, その他いくつかの先端的研究開発は, 研究者が意 識しているかどうかは別として，すでに実世界メディア技 術を目指す方向に動いている．例えば医療応用マイクロシ ステムは，人体と医師の間のインタラクションを円滑にす る実世界メディアとして捉えることができ，メディアとし ての設計指針が重要になる．私の研究室でも，すでに 1990 年に, 実世界メディア技術としてのヒューマン・ロボット・ コンピュータインタラクションの研究開発を開始している [1].

複雑な環境と人間の円滑なインタラクションを媒介する メディアとしてのロボットには, 複雑な情報処理を高速で 行うコンピュータ，あるいはコンピュータネットワークが 必須である。もちろん，情報処理技術に限っても，例えば センサ・アクチュエータ間の反射系のようにコンピュータ 処理が二の次になる部分もあり，また次世代ロボット技術 が機械, 制御, 電気電子といった分野の総合技術であるこ とに変わりはないだろうが（ケミカルロボットはもっと未 来の話だろう)，コンピュータサイエンスから見ても，実 世界メディアとしてのロボットをセンサとアクチュエータ を持つコンピューティングシステムとみなせる時代がすで に来ている.

原稿受付 1997 年 12 月 8 日

キーワード: Network, Real-world Oriented Computing,

Design

* $\bar{T} 223$ 横浜市港北区日吉 3-14-1

*Yokohama-shi, Kanagawa
要約すれば，次世代ロボット技術の一つの大きな目標は， ロボットの機能としては実世界メディア，システム自体と しては広義のコンピューティングシステムの体系的実現と いうことである。また，複雑な環境と複雑な人間行為の間 のメディアとしての次世代ロボットは，用途に応じて極め て多様な形と機能を個々に持つことになるであろう。また それらのロボットがある意味でネットワーク化されること になるであろう。これらが次世代ロボット技術に対する私 の現時点での考え方である.

\section{2. 実世界指向コンピューティングシステム}

さて，上でコンピュータでなくコンピューティングシス テムと言ったのは, 単体のコンピュータを想像してほしく ない（むしろコンピュータネットワークを想像したほうが 適切である) からと,「コンピューティング」という言葉の 意味にはいわゆるコンピュータによる情報処理だけでなく ロボットのセンシングやアクションも含まれるからである. 例えば，ロボットの要素的アクションの遷移は遷移動作を 含む状態遷移グラフとして定式化でき，適切な状態遷移 を行うためのプロトコルを直接サポートするロボット制御 用リアルタイム基本ソフトウェアを構成することができる [2]. また, 分散コンピュータネットワークへのコンピュー ティングシステムとしてのロボットの導入が進み [3], アプ リケーションにおいても分散インタフェース技術が必要に なる [4].もっと現場に近いモニタリング, 制御, 安全管理 などについても，コンピューティングシステム技術として のロボット技術が大きな役割を果たすことになる [5].

コンピュータやヴァーチャルリアリティシステムが現実 の物理的空間とは異なるいわば仮想的な世界を扱っている のに対して，上の意味でのロボットは，コンピューティン グシステムでありながら物理的空間をセンシングし，ま た物理的空間にはたらきかけることができる。つまり，コ ンピュータが仮想世界指向コンピューティングシステムで あるのに対して，上の意味でのロボットは実世界指向コン ピューティングシステムである，さきに述べたことの繰り 返しになるが，次世代ロボット技術は，実世界メディアの 実現を目指して，実世界指向コンピューティングシステム 
技術の開発に向かうことになるだろう。

なお, ヒューマンコンピュータインタラクションの研究 分野では，実世界指向インタフェースという言葉が使われ ている。この言葉は, カメラやその他のセンサを使って物 理的空間の情報をできるかぎり直接的にコンピュー夕に取 り込み，空間に対してユーザがなんらかの行動を容易に 起こせるようにするためのインタフェースを指し，すでに 様々なシステムの開発が試みられている.

さきに述べた実世界指向コンピューティングシステムと こうしたヒューマンインタフェースの違いは, 前者が物理 的空間のセンシングや空間へのアクションをコンピュー ティングとして捉え，コンピュータの扱っている仮想的世 界のコンピューティングと統合的に扱うことを基盤として いるのに対して, 後者はコンピューティングを仮想的世界 に限っている点にある．もちろん開発が進めばその境界は あいまいになっていくだろうし，物理的空間と仮想的空間 におけるコンピューティングの統合的取扱いに関する理論 的研究が完成しているわけではないから, 違いは今のとこ ろいわばコントラストとしてのことと理解されたい.

\section{3. 人工知能の研究}

次世代ロボットの機能や形は, メディアとしての様々な 機能を求めて, レスポンシヴ, リアルタイム, 分散, その 他相当に多様化されていくに違いない. 人工知能の技術も そのなかの一部として活かされていくであろう.

ところが, 次世代ロボット技術というと, まず人工知能 や知能ロボットのことを思い浮かべる人も多い。ここでは その点について考えよう。

「知能を持ったコンピュータやロボットを作る」という目 標の立て方は，できるかどうかは別として，一般の人々に はとても分かりやすいらしい. マスコミばかりか研究者で さえ，人に対してはそうした研究目標を期待する人が多い ようである.

しかし，一般的な意味での知能を持った機械（あるいは 持っているように感じる機械でもよい) を一挙に作るとい うことを試みる研究者が実際にいるのだろうか. 人間の知 能がそんなに容易に機械によって実現できると考えるとし たら，その人はよほどの楽天家であろう. 例えば認知科学 の研究の多くがやってきたのは，人間の知能のある特定の 側面を理解することであって，知能一般を理解することで はない（例えば文献 [6]). (なお，認知科学の教えるところ によれば人間の短期記憶容量はある意味で相当に小さい。 「知能を持ったコンピュータやロボットを作る」といった 研究開発目標を, 実際にはそんな目標を具体的にもって研 究する人などほとんどいないのに多くの人が思い浮かべや すく言いやすい大きな理由は，このような言い方が短期記 憶に簢単に保持でき，イメージしやすい小さな意味語句に
なっているからではないか，というのが私の仮説である.） チェスという完全情報二人ゲーム用の探索専用コンピュー タであるディープブルーが人間に勝ったということと，一 般知能機械の実現が未だ夢に過ぎないということを，混同 して議論する時代ではないと思うが，いかがであろうか.

知能を持った機械を作るべきか，知的に感じる機械を作 るべきか，あるいは知的機械は作るべきでないのか，といっ た杽論は，先端技術研究者にはあまり意味がないのではな いか. 例えば，科学として知能の特定の側面を理解しょう とするとコンピュータを用いるのがベターな方法になりう ること(例えば問題解決のための思考プロセスの説明), 工 学として機械のデザインをしょうとすると知的に感じる機 械を作るのがベターな方法になりうること（例えば運転席 のボタンですべての窓の開閉ができる自動車：これを知的 と感じるかどうかは各人の問題で，一般的にいっても何を 「知的に感じる」かどうかは個人に依存する), 内部のメカ ニズムがはっきり分かる機械を作ったほうがよい場合があ ること（例えば子ども用の自転車）など，相互に矛盾する ことではない.

飛行機を設計するのに鳥の研究が必要か，という話があ る．ここではそれについての細かい議論は省略するが，い ずれにしてもこのようなアナロジーはあまり意味がないの ではないか. 知能を持たないが知能「を感じて」しまうシ ステムと, 知能を持つシステムとは, どこが違うのだろう か. その違いを云々するほど私たちには人間が分かってい ない．また機械についても分かっていない．少なくとも私 自身が興味を抱くのは，人間を情報の面から理解すること， ならびに人間生活の質の向上に役立つ技術の体系を作るこ とであって，鳥と飛行機の違いを議論することではない.

\section{4. ヒューマノイドの研究}

メディアとは複雑な環境と複雑な人間行動の媒介をする ものと考えると，次世代ロボットがメディアの役割を果た すということは，ロボットの機能も形も利用の目的によっ て相当の多様化が図られることを意味する。

そのことを踏まえたうえで，最近よく言われるヒューマ ノイドについて考えてみよう。

人間に近いスピードで階段を昇り降りできる，人間に似 た形の等身大の二足歩行ロボット，いわゆるヒューマノイ ドが開発されている。このようなロボットには多くの人が 人間っぽい雲囲気を感じてしまう。それには，人間が人間 を知覚する，おそらくは先天的能力としての対人知覚の基 本的能力が重要な役割を果しているように思われる。例え ば人間の体にいくつかのランプをつけて点灯し，暗闇のな かを歩かせると，動いて見えるのはそれらのランプだけな のに人間が歩いているように感じられる，ある意味で生ま れながらにして持っていると思われるこのような対人知覚 
能力を意識下で発揮させてしまう工学的システムは，人間 の能力のある側面を「持っている」と言えるのか，言えな いのか, どちらとも言えるのではないだろうか.

ヒューマノイドに対して人が嫌悪感を抱くことがあるの は次の理由による，というのが私の仮説である。つまり， 意識下で自律的にはたらく対人知覚機能によって相手は人 間だと知覚されてしまう。ところが意識のうえでは相手が 機械であって人間ではないと信じている。この自動的知覚 信念の矛盾から心の諸機能を守る制御のために，ある種の 感情状態が引き起こされる．この状態が嫌悪感として認識 される，ということである．この仮説が正しいかどうかは 分からないし，私以外に唱えている人を知っているわけで はない．ただ，なんとなく当たっているように思うがいか がなものだろうか.

話は技術の話題からずれたが，上の仮説を援用すると， 特定のヒューマノイドを開発すべきかどうかについての判 断は, 人間の意識と意識下の情報処理になんらかの意味で 矛盾を起こさせるような機械の開発は行うべきではない, という社会的ルールにも基づくことになるかもしれない. そうなると，混乱が起きないことが（技術的にあるいは意 匠として）保証されるようなヒューマノイド以外は開発禁 止とか, 人間の心が混乱するような場面でのヒューマノイ ドの使用禁止，といった時代がくるのかもしれない.

なお，意識下の情報処理にかかわる別の社会的ルールの 例としては，例えばサブリミナル効果（テレビや映画の場 面などにごく短時間同じ映像を挿入することを繰り返すと， 意識のうえでは気づかないがその映像に影響される傾向が あるといわれる）を起こし得る放送や映画の禁止などが挙 げられる。

上のような社会的ルールはもちろん私の夢想に過ぎな い.今の時点では，ヒューマノイドの開発が妥当かどうか は研究者の目的次第だと思う。私は次世代ロボット技術の 一つの方向が人間と環境の間の円滑なインタラクションを サポートする実世界メディア技術になると考えているが, その延長で言えば，ヒューマノイドもある特定の側面で実 世界メディアの実現に役立つかもしれない，例えば，人間 の形に似せることで，ユーザの体の形や動きや機能に適応 して動く（例えばユーザの顔に近いところで発話しながら そのユーザの手に物体を渡しながらそのユーザの歩行に合 わせて歩く）とか，ジェスチャによる指令で極限作業にお いてジェスチャと同様の動きをするとか，多目的かつ実時 間でしかも直接の相手が人間であるような場合にその人間 との円滑なインタラクションを図るためには，ロボットも 人間に近い形と機能を持っていたほうが機械としての目的 が果たしやすい場合があるかもしれない.

また，ヒューマノイドの開発自体を自己目的とする研究 も，副産物として多くの先端技術を生み出すだろう，ヒュー
マノイドとして現実の世界に応用可能でコストも見合うと ころまで近い将来に技術が届くかどうか，すべての未来技 術のなかでのヒューマノイド開発のプライオリティをどの あたりに置くべきか，人間の心に混乱をきたさないように 設計規制をすべきかどうか，といった問題は別のこととし て，ヒューマノイド開発自体に異議を唱える強い理由を今 のところ私自身は持っていない.

\section{5. デザインの概念と 21 世紀の工学}

人間の能力を拡張する機械（ソフトウェアを含む）の研 究は, 工学全体にとって極めて重要である．特に，機械と 人間のインタラクション，機械を利用した人間同士のイン タラクション，機械が環境や人間に与える影響などを考亚 した機械のデザイン方法の研究と教育は，これからの工学 にとって最重要課題の一つである．アナリシスと違ってシ ンセシスや設計やデザインには答えがない.「設計」という 言葉は，ある程度の仕様が外から与えられた「シンセシス」 の行為を指すことが多いが，「デザイン」とは，仕様や使 用状況設定がまったく（あるいはほとんど）与えられてお らず，得られるプロダクトだけでなくそのプロダクトの存 在や使用が将来にわたって及ほすと考えられる社会的影響, プロダクトと人間の時空間的・意味的インタラクションま でできるかぎり考慮した設計行為，設計のプロセス，ある いは設計の結果を指す（というのが私の粗い定義である）. 例えば光のデザインで世界的に著名な石井幹子氏（現慶應 義塾大学理工学部特別招聘教授) の「デザイン」は, 光と 空間と物理的構造と人間のインタラクションにかかわるう えの意味でのデザインにほかならない，と私は思う.

この意味でのデザイン能力は，必要な情報を本質的に不 完全にしか得ることのできない，また予測も困難な状況に 対するスキルであり，唯一の答を求めがちなアナリシス中 心の 20 世紀の工学のスキルとは極めて異なる，いわば「諸 般の事情を考慮したバランス感覚」が求められる能力であ ると考えられる。

誤解を恐れずに言えば，20世紀の工学は「自然科学の後 追い」の時代であった．特に大学の工学者は, 自然科学者 の真似をして疑似科学の衣装をまとった論文を書き続け， その結果人間や社会と乘離していった面が強い。それは, 19 世紀ドイツに始まるフンボルト流の自然理解的な科学研 究や 20 世紀アメリカで全盛を迎えた専門的大学院の考え 方が影響を与えているからかもしれない。また，自然科学 の後追いとしての工学が 19 世紀から 20 世紀末の今日まで 収めてきた多くの成功が後押ししているからかもしれない。

しかし一方で，要素技術は最先端を行っているのに私た ち自身はあまりに人工的で脆弱な社会基盤の上で暮らさな ければならなくなっていることには，こうした工学の流れ にも結果的に責任がある．21 世紀には，私たちが安心して 
暮らせる知的社会基盤（intelligent social infrastructure） を，工学の多くの分野に携わる人々が中心となって新たに 創造していかなければならない. そのためには工学自体を 変えていかなければならない。この努力は一つには上述の 意味でのデザインのための努力であり，21 世紀は一つには 「デザインとしての工学」の時代として捉えることができ るだろう。（慶應義塾大学理工学部が平成 8 年 4 月に全国 に先駆けてシステムデザイン工学科を設置したのはこの理 由によるところが大きい.）

竹内氏が知能を持った機械ではなく「スマートな」機械 の重要性を示唆しているのは，私にはこうした時代の流れ に沿った貴重なご意見のように思える。つまり，竹内氏の 言われる，やるべきことをきちんとやってくれる機械とは， 大きく言えば，私たちが安心して暮らせる生活基盤を私た ちにとって安全にしっかりと担うことのできる機械という ことであり，さきに述べた意味でのデザインの本質を突い ているのである.

なお「デザイン」という言葉の遣い方については，竹内 氏と私では多少異なっているように思われる．竹内氏のほ うが通常遣われているデザインの語の用法に近いような気 がする，ただし，両者の用法どちらをとるとしても，いわ ゆる人工知能や知能ロボットの先端技術の世界では, デザ インのことはあまり意識されていないように思える。（も ちろん, 設計エキスパートシステムの研究などは行われて きたが, ここで言いたいのは設計のための推論技術のこと だけではない）例えば，人間・機械システムにとって不 測の事態が起こったとき（災害のような緊急事態を考えれ ばよい)，どんな情報を誰がどんなルートでどんな媒体と 表現で流せばよいのかといった，デザインのための常識的 事項について，人工知能や知能ロボット（だけでなく多く の情報関連分野の）研究者がどの程度頭に置いているかと いうと，心もとないように思える。

実世界メディア技術としての次世代ロボット技術は，実 世界の構造と機能を人間の複雑な行為に適応可能にすると いう点で，さきの意味での「デザイン」に大きく役立つ可 能性を秘めている．現時点をとれば技術的にできることは いまだ限られているが, 先端ロボット・コンピュー夕技術 の急速な発展に一面の関与をしている者として,「デザイ ンとしての工学」への次世代ロボット技術の寄与は今後極 めて大きくなるように予感される。

\section{6. おわりに}

次世代ロボット技術のことと竹内氏の論点についてコメ ントするつもりで書き始めたのが，随分と大きな話になっ てしまった，本稿で最初に述べたような実世界メディア技 術の観点に立てば，次世代ロボット技術は，私たちの生活 基盤に対してもまた産業界に対しても，広くインパクトを 与え得るに違いない，また，本稿の後半で述べた意味で， 実世界メディア技術は 21 世紀における「デザインとして の工学」の大きな方法論を形成することになるであろう. 人工知能やヒューマノイドの新しい研究もそのなかの一部 として活かされていくだろうが，大きな流れとしては，メ ディアとしてのロボットの形や機能については必然的に相 当な多様化が進んでいくであろう.

実世界指向メディア技術としての次世代ロボット技術を はじめとして,「デザインとしての工学」の 21 世紀にどん な先端技術が生まれ育つのか，まことに楽しみである。

\section{参 考 文 献}

[1] Y. Anzai: "Human-robot-computer interaction: A new paradaigm of research in robotics," Advanced Robotics, vol.8, no.4, pp.357-369, 1994.

[2] T. Yakoh and Y. Anzai: "A new reactive operating system for human-robot-computer interaction," Advanced Robotics, vol.8, no.4, pp.371-383, 1994 .

[3] 中内, 川杉, 岡田, 山崎, 安西: “RT-Michele: 分散環境に対応し たヒューマン・ロボット・インタフェースシステム”, 日本ロボット 学会誌, vol.12, no.3, pp.431-438, 1994.

[4] Y. Iwakura, Y. Shiraishi, Y. Nakauchi and Y. Anzai: "Realworld Oriented Distributed Human-Robot Interface System," Proc. of IEEE International Workshop on Robot and Human Communication, pp.188-193, 1997

[5] “知的社会基盤工学技術一超安心社会を支える基盤技術—”, 新エネ ルギー・産業技術総合開発機構, NEDO-IT-9506, 1996.

[6] 安西, 石崎, 大津, 波多野, 溝口 (編)：認知科学ハンドブック. 共 立出版, 1992 .

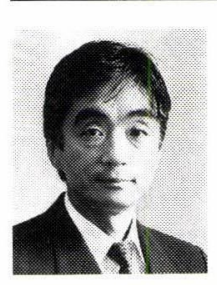

博士.
安西祐一郎 (Yuichiro Anzai)

1946 年 8 月 29 日生. 1974 年慶應義塾大学 大学院博士課程修了. 1988 年上り慶應義熟大 学理工学部教授. 1989 年より同大学大学院計 算機科学専攻教授兼任. この間, $1981 \sim 82$ 年 カーネギーメロン大学客員助教授. 計算機科 学, 認知の情報処理過程の研究に従事. 工学 （日本ロボット学会正会員） 